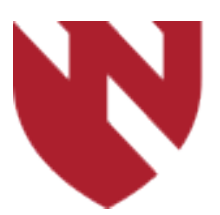

December 2019

\title{
Stereotactic Body Radiotherapy versus Non-Radiotherapeutic Ablative Procedures for Early Stage Non-Small Cell Lung Cancer
}

\author{
Michael J. Baine \\ University of Nebraska Medical Center \\ Richard Sleightholm \\ University of Nebraska Medical Center \\ Beth Neilsen \\ University of Nebraska Medical Center \\ David Oupicky \\ University of Nebraska Medical Center \\ Lynette M. Smith \\ University of Nebraska Medical Center
}

See next page for additional authors

Tell us how you used this information in this short survey.

Follow this and additional works at: https://digitalcommons.unmc.edu/gmerj

Part of the Higher Education Commons, and the Medicine and Health Sciences Commons

\section{Recommended Citation}

Baine, M. J., Sleightholm, R., Neilsen, B., Oupicky, D., Smith, L. M., Verma, V., , Lin, C. Stereotactic Body Radiotherapy versus Non-Radiotherapeutic Ablative Procedures for Early Stage Non-Small Cell Lung Cancer. Graduate Medical Education Research Journal. 2019 Dec 13; 1(1).

https://digitalcommons.unmc.edu/gmerj/vol1/iss1/28

This Conference Proceeding is brought to you for free and open access by DigitalCommons@UNMC. It has been accepted for inclusion in Graduate Medical Education Research Journal by an authorized editor of DigitalCommons@UNMC. For more information, please contact digitalcommons@unmc.edu. 
Stereotactic Body Radiotherapy versus Non-Radiotherapeutic Ablative

Procedures for Early Stage Non-Small Cell Lung Cancer

\section{Creative Commons License}

\section{c) (1)@ $\Theta$}

This work is licensed under a Creative Commons Attribution-Noncommercial-No Derivative Works 4.0 License.

Authors

Michael J. Baine, Richard Sleightholm, Beth Neilsen, David Oupicky, Lynette M. Smith, Vivek Verma, and Chi Lin 


\section{Stereotactic Body Radiotherapy versus Non-Radiotherapeutic Ablative Procedures for Early Stage Non-Small Cell Lung Cancer \\ Michael J Baine*, Richard Sleightholm*, Beth Neilsen, David Oupický, Lynette M Smith, Vivek Verma, Chi Lin}

*These authors contributed equally

Mentor: Chi Lin

Program: Radiation Oncology

Introduction: Despite the fact that stereotactic body radiation therapy (SBRT) is the only recommended first-line therapy for inoperable early stage NSCLC, several thermal ablative procedures (TAPs) are available. Outcomes from these procedures, and how they compare to SBRT, are scarce. We sought to evaluate the comparative efficacy of SBRT versus TAPs using the National Cancer Database (NCDB).

Methods: The NCDB (2004-2014) was queried for early stage NSCLC patients who did not undergo surgical resection. Treatment- specific inclusion criteria were applied to select for patients as receiving either TAPs or SBRT. Univariate logistic regression, Cox proportional hazard modeling, and Kaplan-Meier (KM) curves were performed. Propensity matching was performed using a modified Greedy $8 \rightarrow \mathrm{n}$ matching 1:1 algorithm.

Results: 27,734 patients were analyzed; 26,725 underwent SBRT and 1,009 underwent IR-procedures. Patients who received SBRT were older and more likely to have clinical stage 1B disease. Despite this, SBRT was associated with longer median overall survival (OS) (37.7 vs 33.5 months, $\mathrm{p}=0.001$ ) and 1, 2, and 5 year OS than the IR cohort at $86.7 \%$ vs
$83.1 \%, 67.5 \%$ vs $62.7 \%$, and $30.6 \%$ vs $26.9 \%$, respectively $(\mathrm{p}=0.001)$. Upon propensity matching, the improved OS with SBRT remained with a median OS of 40.4 months vs 33.4 months and 1, 2, and 5 year OS of $89.0 \%$ vs $82.9 \%, 69.7 \%$ vs $62.7 \%$, and $34.4 \%$ vs $26.4 \%$, respectively $(\mathrm{p}=0.0033)$.

Conclusions: Despite being associated with multiple poor prognostic features, SBRT was associated with higher OS over TAPs for treatment of non-operative patients diagnosed with early-stage NSCLC.

https://doi.org/10.32873/unmc.dc.gmerj.1.1.028

\section{Non Neurofibromatosis-1 Scalp Malignant Nerve Sheath Sarcoma with Non-Confluent Parotid Metastasis: Rare Case and Review of Literature Alejandro Wolf, Chandra Srinivasa}

Mentor: Chandra Srinivasa

Program: Pathology

Objective: To delineate a distinct clinical, pathological, immunohistochemical distinguishing features, and management of malignant peripheral nerve sheath tumor of the scalp.

Methods: We performed pathology evaluation of specimen and conduct review of the literature regarding the clinical presentation, diagnosis, treatment modalities, and outcome for MPNSTs in this anatomic location.

Results: In patients with neurofibromatosis type 1 (NF1), approximately 5 in 10 MPNSTs arise from neurofibromas. Overall MPNST has a prevalence of $0.001 \%$ in the general population. Only a few cases of MPNSTs have been reported to have originated in the skin accounting for approximately $2-9 \%$ of all MPNSTs. Of those, $50 \%$ are in the head and neck, with the scalp as the main location. Although there are only a few reports of MPNSTs arising primarily in the parotid gland, apart from our case, there are only two previous cases of an MPNST metastasizing to the parotid gland. None of the cases with metastasis to the parotid appears to have had neurofibromatosis.

Conclusion: The superficial MPNSTs derive from cutaneous neurofibromas or small peripheral nerves, and are markedly aggressive with rapid invasive growth, recurrence after excision, and early hematogenous dissemination. Immunohistochemically, S100 staining is positive in up to $50 \%$. There is no genetic difference between NF1-associated and sporadic tumors. Surgical treatment with margins greater or equal to $2 \mathrm{~cm}$ and adjuvant radiation must be considered as a standard treatment. Negative-pressure wound VAC therapy, fascial or muscular flaps with microvascular anastomosis are ideal for reconstruction.

https://doi.org/10.32873/unmc.dc.gmerj.1.1.029

\section{Effectiveness of Advanced Pupil Simulator for Teaching Pupillary Abnormalities: A Pilot Study on Medical Students, Neurology and Ophthalmology Residents \\ Jideofor K Ndulue, Deepta Ghate, Kedar Sachin}

Mentors: Deepta Ghate, Kedar Sachin

Program: Truhlsen Eye Institute

Background: We recently designed a virtual reality-based application, Advanced Pupil Simulator $^{\circledR}$, and herein report the results of training with this device on trainee selfperceived confidence and competence to perform pupillary examination.

Methods: Participants included 145 trainees (126 first-year medical students, 15 neurology and 4 ophthalmology residents). All trainees reviewed an online power-point module and practiced pupillary examination in groups of 3 assigned to a simulator and expert faculty for 30 minutes. All trainees completed a Likerttype questionnaire $(1=$ not confident, $5=$ very confident) assessing confidence to perform pupillary examination before and after the study. All trainees were objectively assessed for knowledge, comprehension, application and analysis by the faculty. The difference in pre-and post-training confidence was tested using Wilcoxon sign rank test. Group differences in objective scores were tested using Fischer's exact test.

Results: 97\% (122) students and 10 (52\%) residents reported improved confidence in performing pupil examination following training. 80\% (101) students and 89\% (17) residents were able to correctly list and demonstrate all steps in the pupil examination. $77 \%$ (97) students and 74\% (14) residents 